JOURNAL OF SECURITY AND SUSTAINABILITY ISSUES

ISSN 2029-7017 print/ISSN 2029-7025 online

2022 Volume 12

http://doi.org/10.47459/jssi.2022.12.1

\title{
IMPACT OF COVID-19 PANDEMIC ON ECONOMIC SECURITY - MULTIDIMENSIONAL ANALYSIS OF REAL ESTATE MARKET ACROSS POLAND
}

\author{
Bartosz Kozicki ${ }^{1,}$ Andrzej Wloch ${ }^{2}$, Radosław Grabowski ${ }^{3}$, Szymon Mitkow ${ }^{4}$ \\ ${ }^{1.4}$ Military University of Technology, gen. Sylwestra Kaliskiego 2, 00-908 Warszawa, Poland \\ ${ }^{2}$ Rzeszow University of Technology, Aleja Powstańców Warszawy 12, 35-959 Rzeszów, Poland \\ ${ }^{3}$ University of Rzeszow, aleja Tadeusza Rejtana 16C, 35-310 Rzeszów, Poland \\ E-mail: ${ }^{1}$ bartosz.kozicki@wat.edu.pl; ${ }^{2} a w l o c h @ p r z . e d u . p l ;{ }^{3}$ rgrabowski@ur.edu.pl; ${ }^{4}$ szymon.mitkow@wat.edu.pl
}

Received 15 November 2021; accepted 12 January 2022; published 15 February 2022

\begin{abstract}
Economic security of any state is multifaceted. Affordability of basics, required for living serves are precondition for economic security of any state. The study presents a multidimensional comparative analysis of apartment sales in respective voivodships in Poland. The following dependent variables concerning apartments in sixteen voivodships were analyzed: price per $\mathrm{m}^{2}$, number of sales and its value. The dynamics indices on a constant basis and the normalization for stimulants were used for the analyzes. The results of the research were compiled on categorized bar charts, conducting the ranking, as well as indicating and outlining the level of deviation of the analyzed data adopted by the author. The conducted research clearly showed how much of an impact on the state's economy, with particular emphasis on the subject of research presented in the article, which is the apartment trade market, has a random incident, such as a pandemic, and how difficult it is to return to the conditions before Covid-19.
\end{abstract}

Keywords: economic security; real estate market; Poland; COVID-19; multidimensional comparative analysis; stimulant

Reference to this paper should be made as follows: Kozicki, B., Włoch, A., Grabowski, R., Mitkow, S. 2022. Impact of Covid-19 pandemic on economic security: multidimensional analysis of real estate market across Poland. Journal of Security and Sustainability Issues, 12, 5-15. http://doi.org/10.47459/jssi.2022.12.1

JEL Classifications: R1

\section{Introduction}

Economic security of any state is multifaceted (e.g. Chehabeddine, Tvaronavičienè, 2020; Meidute் Kavaliauskienė et al., 2021; Khalatur et al., 2021; Periokaite, Dobrovolskiene, 2021; Beňuška, Nečas, 2021). Affordability of basics, required for living serves are precondition for economic security of any state. The paper is devoted to impact of Covid-19 on real estate market in Poland.

The analysis of secondary data allows for the conclusion that at the beginning of 2020, when the initial restrictions and economic problems caused by COVID-19 emerged, there was a belief on the market that housing prices will drop significantly in the near future. Eventually, analyzing the entire 2020, it did not happen (Rynek Nieruchomości a Covid-19, 2021).

The price is an important financial instrument in the market. It is a tool used by respective market entities. According to S. Owsiak, the price expresses a value of goods, services, currency or production factors in money (Owsiak 2015 , p. 344). It has an impact on the sale volume as the level of supply and demand depends on it. The study attempts to analyze the prices of $1 \mathrm{~m}^{2}$ of living area in respective voivodships in Poland and the sale of apartments in dynamic terms. Initial analyzes and the own experience allowed to present the main research problem of the study. 
The main research problem focuses on a multidimensional comparative analysis of the value of housing sales in Poland in sixteen voivodships between 2015-2020 in terms of the impact of the COVID-19 pandemic and the maintenance of the economic security of the state.

The aim of the study is an attempt to conduct a multidimensional comparative analysis of data on apartment sales in sixteen voivodships in Poland between 2015-2020, their grouping and examining the similarities and differences.

A research hypothesis was outlined for the adopted research problem and the purpose of the work:

To what extent will the application of a multidimensional comparative analysis, including stimulants, allow the examination of the similarities and differences in the value of apartment sales in sixteen respective voivodships in Poland between 2015-2020?

The following research methods were used in the study: analysis of the literature which concerns the issues related to the sale of apartments in sixteen voivodships in Poland in dynamic terms, the COVID-19 pandemic and economic security, as well as multidimensional data analysis.

\section{Analysis of the literature on the research subject}

The infectious disease COVID-19 was and is influencing many sectors of the economy. The transport sector was the first to be clearly affected. Changes related to the impact of COVID-19 can also be observed in the real estate sales market.

COVID-19 was first reported in December 2019 in Wuhan, China (Zhu, Zhang, et al. 2020). On March 11, 2020, the World Health Organization announced the COVID-19 pandemic (Satomi, et al., 2020). By December 7, 2021, approximately 3184676 people had been infected with this disease in Poland, and 86205 died (Zasięg koronawirusa Covid-19, 2021). The high mortality rate of people, as well as the speed of transmission of the disease, led, particularly in the first stage, to many long-term restrictions (Matuka, 2020), e.g. no movement, remote work order. This, in turn, had an impact on the prices on the real estate market in Poland.

The prices of flats in respective voivodships in Poland between 2015-2020 were and are diversified and, in total, they show a growing trend (Kozicki, Mitkow, Sowa, 2021). The information taken from websites shows that the following voivodships are the cheapest in terms of housing prices: Lubuskie, Łódzkie and Świętokrzyskie. The highest prices are definitely in the Mazowieckie Voivodship. In February 2021, the price of $1 \mathrm{~m}^{2}$ of an apartment in Warsaw fluctuated around PLN 10,657. The second place in the ranking was Gdańsk with a price for $1 \mathrm{~m}^{2}$ of PLN 10,267 and the third one was Kraków with a price of PLN 9,744. The COVID-19 pandemic has led to a temporary slowdown in the growth of housing prices, as well as their drops. Forecasts at the beginning of the pandemic indicated a tendency to stop the large increase in housing prices in Poland (Słomski, 2021). This did not happen, despite the fact that in 2020 about 15000 fewer work permits were issued for foreigners, mainly Ukrainians seeking employment in the construction industry, than in 2019 (Sarniewicz, 2021). The largest increase in the prices of residential premises in 2020 was recorded in the Mazowieckie, Podkarpackie and Pomorskie Voivodship (Ceny mieszkań w największych miastach Polski, 2021).

The level of housing prices has an impact on the economic security of the state and its citizens. Economic security is considered to be the certainty of the survival and development of the economic system of the state and international economic organizations, it guarantees the maintenance of an appropriate position in economic relations and a proper standard of living for citizens (Nurzyńska, 2016, p. 22).

According to Eugeniusz Zwierzchowski, ensuring the safety of citizens is one of the basic tasks of the state. Ensuring the safety of citizens consists, inter alia, in various activities undertaken by state authorities in order to protect citizens against the effects of hostilities and terrorist attacks, but also against the threat of domestic crime, the development of epidemic diseases, natural disasters, various types of catastrophes and other threats to the life, health or property of citizens (Zwierzchowski, p. 108). 
Security can be divided according to several criteria (Brzeziński, 2009, p. 33-34, Zwierzchowski E., 2009, p. 95-104). One of them is the subjective criterion, thanks to which it is possible to distinguish political, military, economic, environmental, social security, etc. (Wojtaszczyk, 2021, p. 12, Zięba, 2008, p. 16, Czaputowicz, p. 22-23).

Economic security is related to the provision of economic conditions necessary for the survival, prosperity and sustainable development of society, as well as the efficient functioning of the state and its institutions (Kitler, 2011, p. 49).

According to Szubrycht, this is a state of affairs that allows for the development of the economy and the ensuring of a proper standard of living for citizens through continuous access to raw materials, asset, technology or information (Szubrycht, 2006, p. 87-98).

The study presents a multidimensional comparative analysis of data on apartment sales in respective voivodships in Poland. Such an analysis allows to explain the structure of connections between the observed characteristics of objects (Panek, Zwierzchowski, 2013, p. 15). It belongs to the group of statistical methods by means of which at least two variables describing each object are subjected to simultaneous analysis (Luniewska, Tarczyński, 2006, p. 9).

During the research, normalization for the stimulants was used (Mitkow, Tomaszewski, Kozicki, 2021, p. 110-160). On the other hand, a stimulant is a form of data normalization based on the assumption that the higher the value of the stimulant, the higher its rank.

\section{Multidimensional analysis of apartment sales in voivodships in Poland}

The research began with a bar chart of prices in PLN in PLN for $1 \mathrm{~m}^{2}$ of usable floor space in total in 16 voivodships in Poland between 2015-2020 in Figure 1.

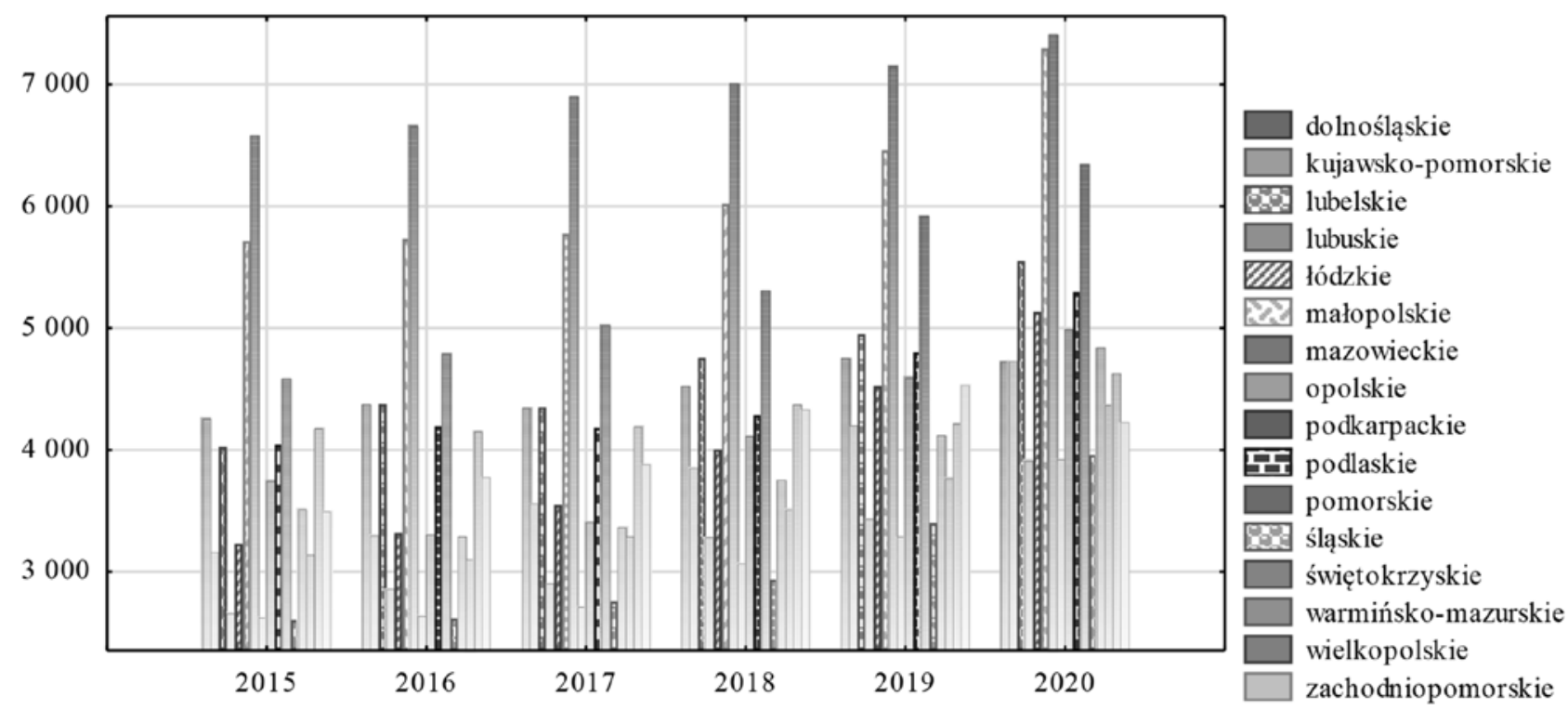

Figure 1. Prices of $1 \mathrm{~m} 2$ of usable floor space in total in 16 voivodships in Poland in 2015-2020 in PLN

Source: own study based on data obtained from the website: https://bdl.stat.gov.pl/ 03.12.2021

Figure 1 shows that the leader in terms of the highest price of $1 \mathrm{~m}^{2}$ of living space in Poland is the Mazowieckie Voivodship. From 2015 to 2020, a growing trend in the prices of $1 \mathrm{~m}^{2}$ of usable space can also be observed in this voivodship. The arithmetic mean of the price of $1 \mathrm{~m}^{2}$ of usable floor space of a flat between 2015-2020 was PLN 6949 PLN. 
The second place in the ranking of the highest prices for $1 \mathrm{~m}^{2}$ of usable floor space of flats in Poland is the Małopolskie Voivodship. A growing trend is also visible here. The arithmetic mean of prices for $1 \mathrm{~m}^{2}$ of usable space between 2015-2020 was PLN 6167 PLN.

The third place in terms of the highest prices for $1 \mathrm{~m}^{2}$ of usable space is occupied by the Pomorskie Voivodship with a visible growing trend from 2015 to 2020. The arithmetic mean of the price of $1 \mathrm{~m}^{2}$ of usable space was PLN 5326 PLN.

The fourth place in this ranking was taken by the Lubelskie Voivodship. The upward trend in the price of $1 \mathrm{~m}^{2}$ of living space was visible here from 2015 to 2016 and from 2017 to 2020 . The arithmetic mean of prices for $1 \mathrm{~m}^{2}$ of residential space in the period from 2015 to 2020 was PLN 4 668,167 PLN. The ranking of the remaining 12 voivodships together with the arithmetic means of prices for $1 \mathrm{~m}^{2}$ of living space for $2015-2020$ is as follows:

5 - dolnośląskie: 4494 PLN;

6 - podlaskie: 4467 PLN;

7 - wielkopolskie: 4 285,833 PLN;

8 - zachodniopomorskie: 4038 PLN;

9 - podkarpackie: 4 022,333 PLN;

10 - łódzkie: 3 960,5 PLN;

11 - świętokrzyskie: 3811 PLN;

12 - kujawsko-pomorskie: 3797 PLN;

13 - warmińsko-mazurskie - 3 526,5 PLN;

14 - lubuskie: 3 172,5 PLN;

15 - śląskie: 3 045,333 PLN;

16 - opolskie: 3039 PLN.

The next stage of the research was the analysis of the dynamics of price changes for $1 \mathrm{~m}^{2}$ of living space in 16 voivodships in Poland between 2015-2020. In order to conduct the research, the indices of dynamics on a constant basis were calculated. The price of $1 \mathrm{~m}^{2}$ of usable floor space of an apartment in 16 voivodships of Poland in 2015 was assumed as a constant. The test results are outlined in Figure 2.

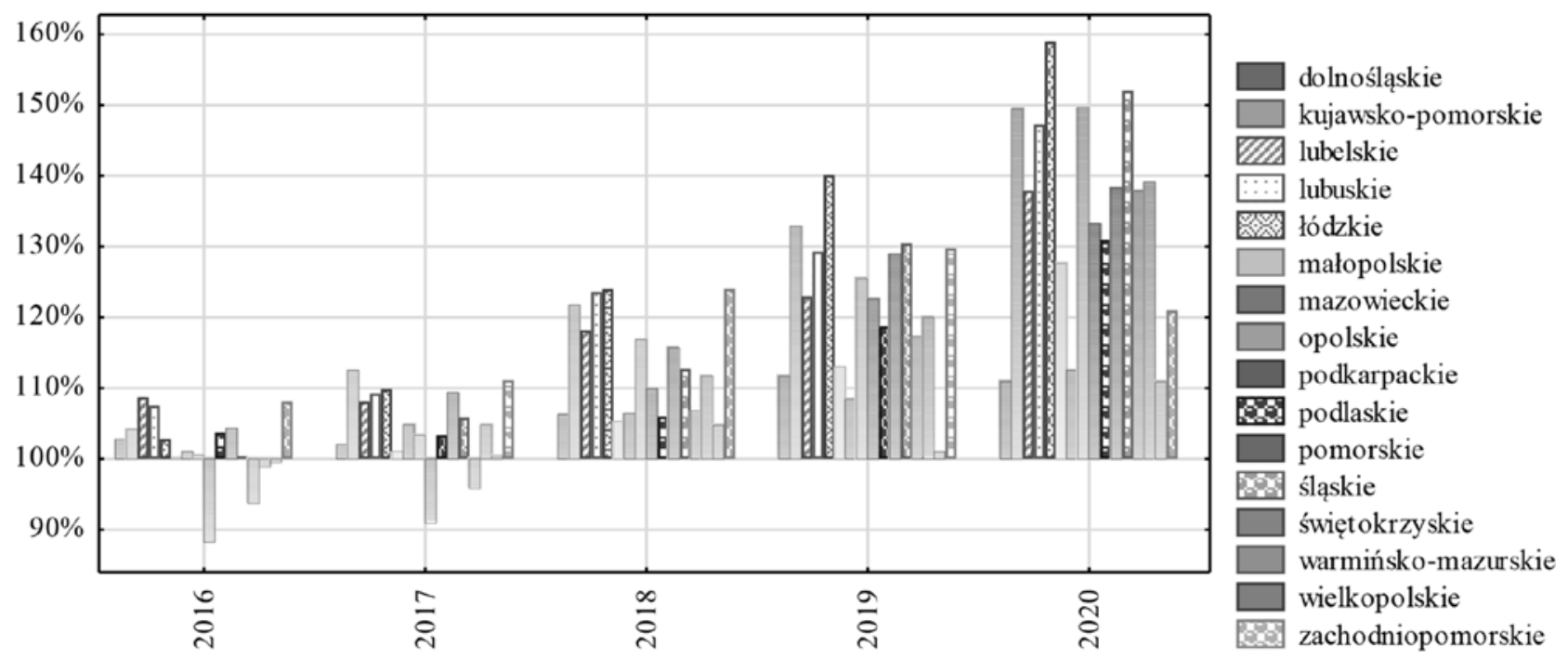

Figure 2. Indices of dynamics of prices of $1 \mathrm{~m}^{2}$ of usable floor space on a constant basis in total in 16 voivodships in Poland between 2016-2020 (constant - the price of $1 \mathrm{~m}^{2}$ of usable floor space in total in 16 voivodships in Poland in 2015)

Source: own study based on data obtained from the website: https://bdl.stat.gov.pl/, 03.12.2021

The data in Figure 2 shows that the highest growth rate of prices for $1 \mathrm{~m}^{2}$ of living space in 16 respective voivodships in Poland between 2015-2020 was in the Lódzkie Voivodship. From 2015 to 2020, there was an increase by $58.95 \mathrm{pp}$. The following voivodships occupy the following places in the ranking, along with the growth from 2015 to 2020 : 
2 - śląskie: 52,02 pp;

3 - opolskie: 49,69 pp.;

4 - kujawsko-pomorskie: 49,45 pp.;

5 - lubuskie: 47,23 pp.;

6 - warmińsko-mazurskie: 39,15 pp.;

7 - pomorskie: 38,31 pp;

8 - lubelskie: 37,91 pp.;

9 - świętokrzyskie: 37,90 pp.;

10 - podkarpackie: $33,30 \mathrm{pp}$.;

11 - podlaskie: $30,96 \mathrm{pp}$;

12 - małopolskie: 27,64 pp.;

13 - zachodniopomorskie: 21,00 pp.;

14 - mazowieckie: $12,61 \mathrm{pp}$;

15 - dolnośląskie: $10,93 \mathrm{pp}$;

16 - wielkopolskie: $10,91 \mathrm{pp}$.

Then, Figure 3 compares the number of flats sold on the free market in Poland in 16 respective voivodships between 2015-2020.

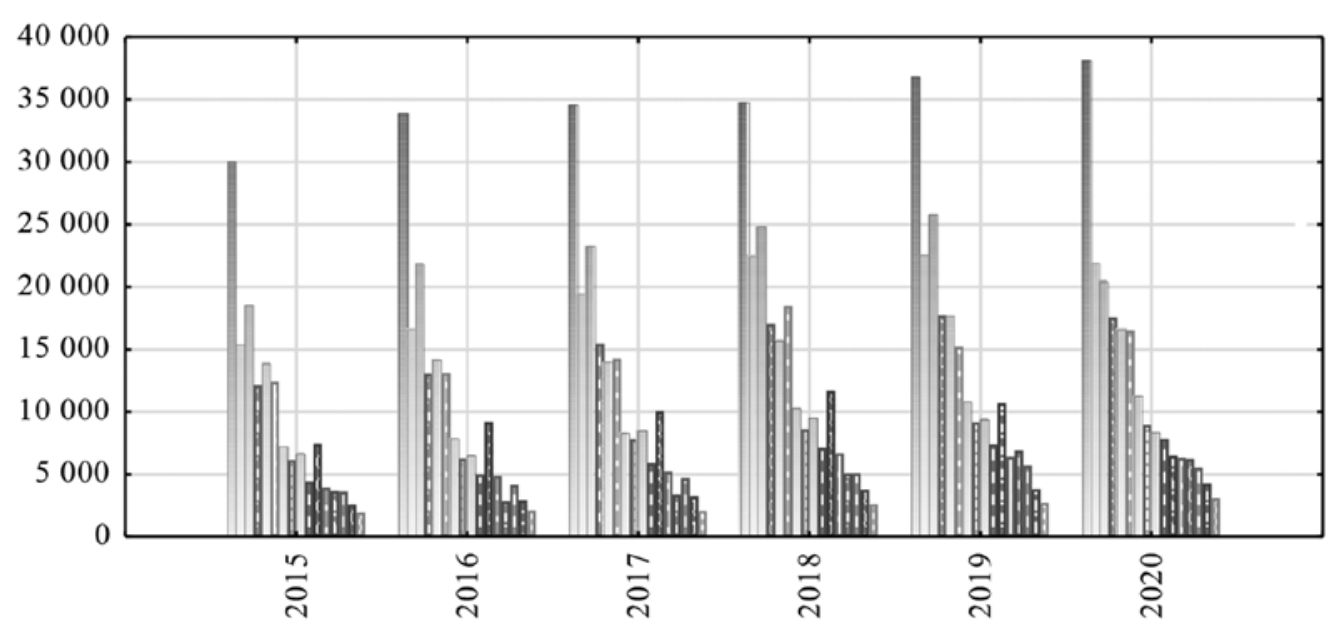

mazowieckie pomorskie dolnośląskie

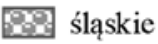
małopolskie 페패 wielkopolskie lódzkie 四囲 warmińsko-mazurskie kujawsko-pomorskie lubelskie B8 zachodniopomorskie 패매 lubuskie 89 podkarpackie $\square$ podlaskie 89 opolskie

Figure 3. Number of flats sold on the free market in 16 voivodships in Poland between 2015-2020

Source: own study based on data obtained from the website: https://bdl.stat.gov.pl/ 03.12.2021

The data presented in Figure 3 shows that the highest sales of flats in the 16 analyzed voivodships in Poland between 2015-2020, along with a visible growing trend, were observed in the Mazowieckie Voivodship.

Figure 3 also shows that in 2020, compared to 2019, for the 16 analyzed voivodships, an increase in the number of flats sold during the COVID-19 pandemic occurred only in six voivodships (ranking plus an increase compared to 2019):

1 - mazowieckie: 1 293; 2 - wielkopolskie: 1 292; 3 - opolskie: 452; 4 - lubelskie: 450; 5 - łódzkie: 423; 6 - świętokrzyskie: 365 .

In the remaining 10 voivodships declines were observed. The ranking of the largest decreases along with the absolute value of the difference between 2019 and 2020 is as follows:

1 - dolnośląskie: 5388; 2 - zachodniopomorskie: 4201; 3 - małopolskie: 1098; 4 - kujawsko-pomorskie: 1016; 5 - podkarpackie: 684; 6 - pomorskie: $668 ; 7$ - warmińsko-mazurskie: $222 ; 8$ - śląskie: $184 ; 9$ - podlaskie: $143 ; 10$ - lubuskie: 89.

The next stage of the research was the analysis of the total value of apartments sold in Poland between 2015-2020 (Fig. 4). 


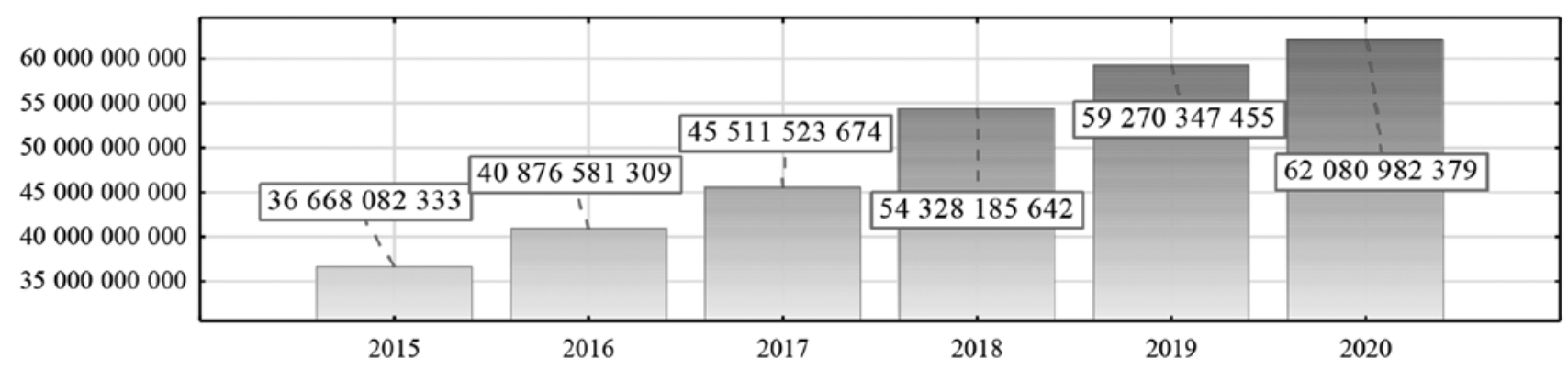

Figure 4. Total value of flats sold on the free market in Poland between 2015-2020 in PLN

Source: own study based on data obtained from the website: https://bdl.stat.gov.pl/, 03.12.2021

The information in Figure 4 shows that the sum of the value of sold apartments in Poland between 2015-2020 indicates a growing trend. The highest increase in the total value of apartments sold was in 2018 and amounted to 8816661968 apartments compared to 2017. On the other hand, the lowest increase is visible in 2020 during the impact of the COVID-19 pandemic. Between 2019 and 2020, there was an increase in the value of flat sales by 2810634 924. The arithmetic mean of the value of flat sales in Poland between 2015-2020 was 49789283799 while the median was 49919854 658. The standard deviation from the arithmetic mean was 10309990080 .

For illustrative purposes, Figure 5 presents the sum of the value of flats sold on the free market in respective 16 voivodships in Poland between 2015-2020 in PLN.

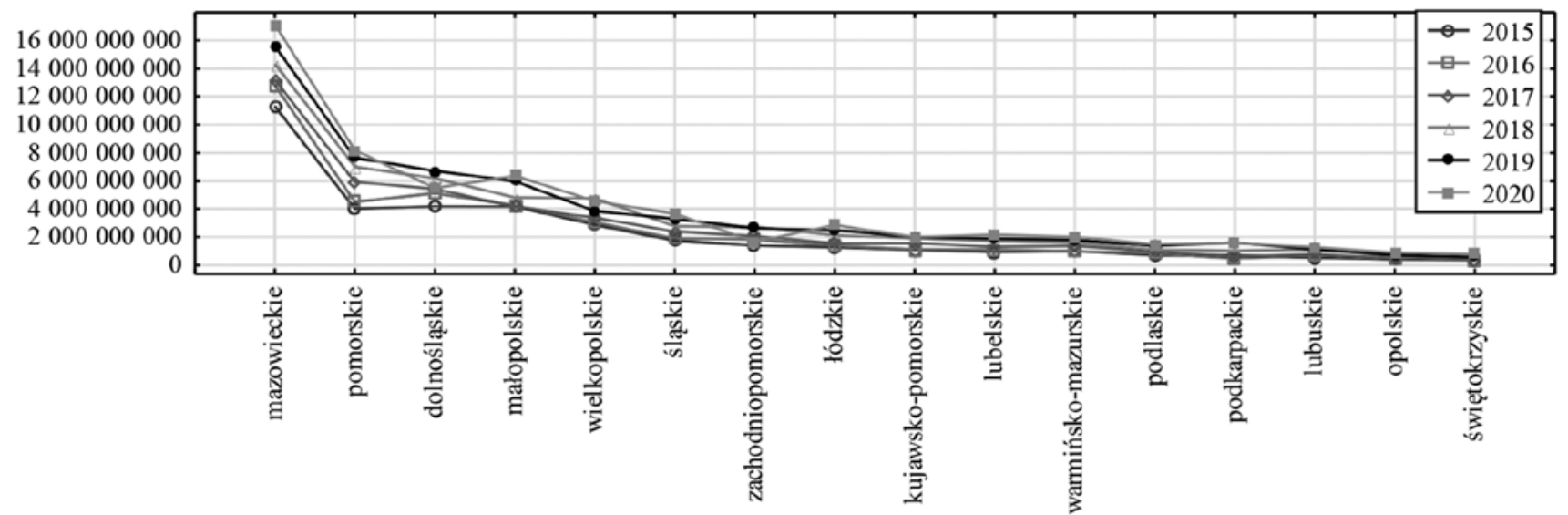

Figure 5. The sum of the value of flats sold on the free market in respective 16 voivodships in Poland between 2015-2020 in PLN

Source: own study based on data obtained from the website: https://bdl.stat.gov.pl/ 03.12.2021

The observations of the data presented in Figure 5 show that the largest sum of the value of flats sold in 16 respective voivodships in Poland between 2015-2020 was in the Mazowieckie Voivodship. The arithmetic mean of the sum of the value of flats sold in this voivodship between 2015-2020 was PLN 14064611 887. The ranking of the remaining voivodships in terms of the arithmetic mean of the sum of flat sales in Poland between 2015-2020, from the highest to the lowest value, is as follows:

2 - pomorskie: 6213900556 PLN; 3 - dolnośląskie: 5516187888 PLN; 4 - małopolskie: 4954774990 PLN; 5 - wielkopolskie: 3740633543 PLN; 6 - śląskie: 2628765343 PLN; 7 - zachodniopomorskie: 2052001076 PLN; 8 - łódzkie: 1949883421 PLN; 9 - kujawsko-pomorskie: 1610789471 PLN; 10 - lubelskie: 1519524293 PLN; 11 - warmińsko-mazurskie: 1457785 174 PLN; 12 - podlaskie: 1079052630 PLN; 13 - podkarpackie: 996156585 PLN; 14 - lubuskie: 921937987 PLN; 15 - opolskie: 595722722 PLN; 16 - świętokrzyskie: 487556234 PLN.

Then, the dynamics of the total value of apartments sold in 16 voivodships in Poland between 2015-2020 was analyzed. The results are outlined in Figure 6. 


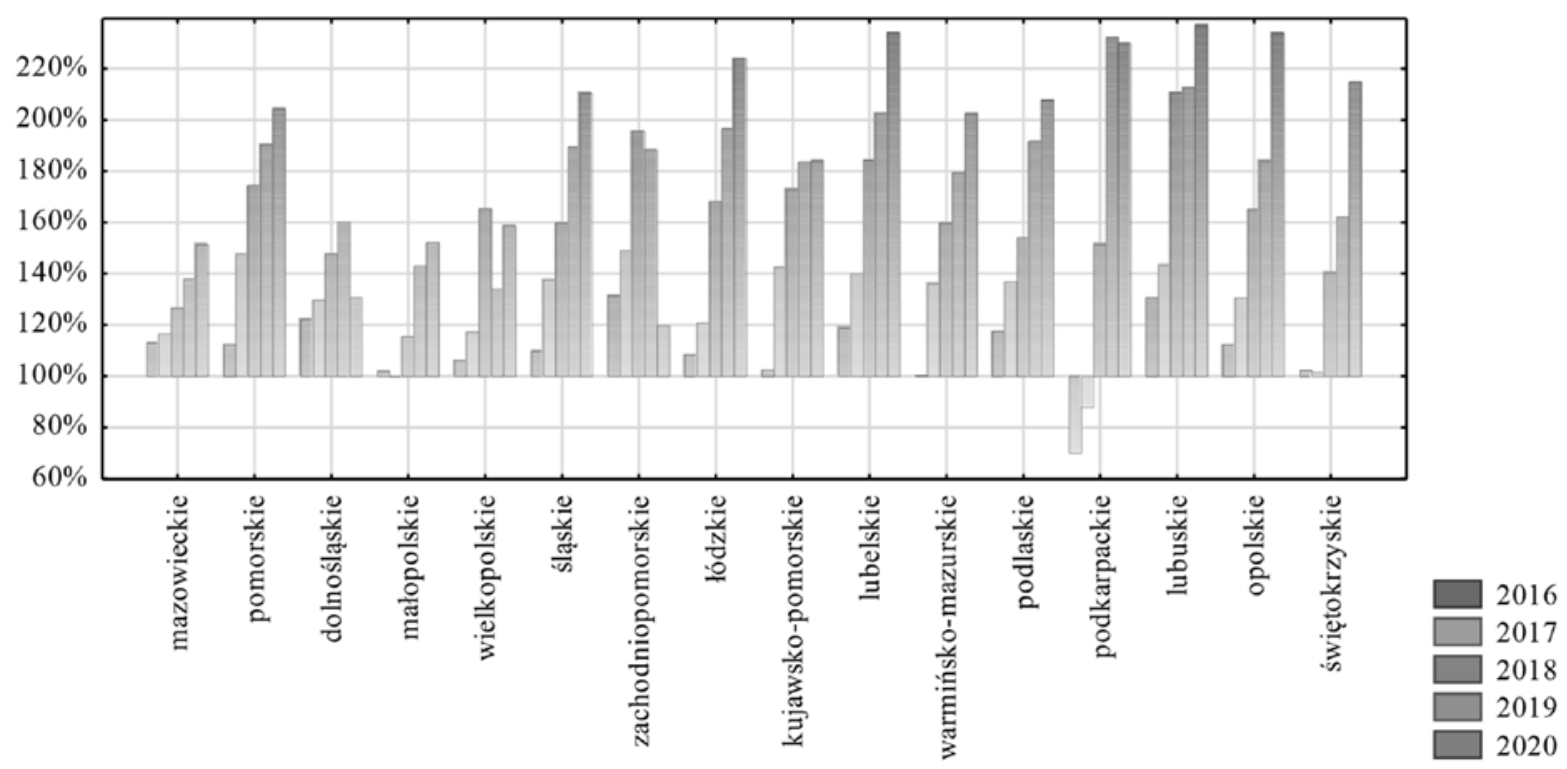

Figure 6. The dynamics index on a constant basis of the value of flats sold on the free market in 16 voivodships in Poland between 2015-2020 in percentage (fixed sum of the value of flats sold in respective 16 voivodships in Poland in 2015)

Source: own study based on data obtained from the website: https://bdl.stat.gov.pl/, 03.12.2021

According to the information in Figure 6, the highest increase in the dynamics of the total value of flats sold in the 16 analyzed voivodships in Poland from 2015 to 2020 was recorded in (from the highest value to the lowest value along with an increase in $\mathrm{pp}$.):

1 - lubuskim: 136,67 pp.;

2 - lubelskim: 134,10 pp.;

3 - opolskim: 133,71 pp.;

4 - podkarpackim: 130,03 pp;

5 - łódzkim: 123,96 pp.;

6 - świętokrzyskim: 114,71 pp.;

7 - śląskim: 110,29 pp.;

8 - podlaskim: 107,74 pp.;

9 - pomorskim: 104,13 pp.;

10 - warmińsko-mazurskim: 102,27 pp.;

11 - kujawsko-pomorskim: 83,95 pp.;

12 - wielkopolskim: 58,74 pp.;

13 - małopolskim: 52,24 pp.;

14 - mazowieckim: 51,32 pp.;

15 - dolnośląskim: 30,71 pp.;

16 - zachodniopomorskim: 19,65 pp.

For research purposes, it was decided to group 16 voivodships analyzed between 2015-2020 with regard to similarities in terms of the sum of the value of apartments sold, using the normalization for stimulants. The test results for illustrative purposes are presented in Figures 7 and 8. 


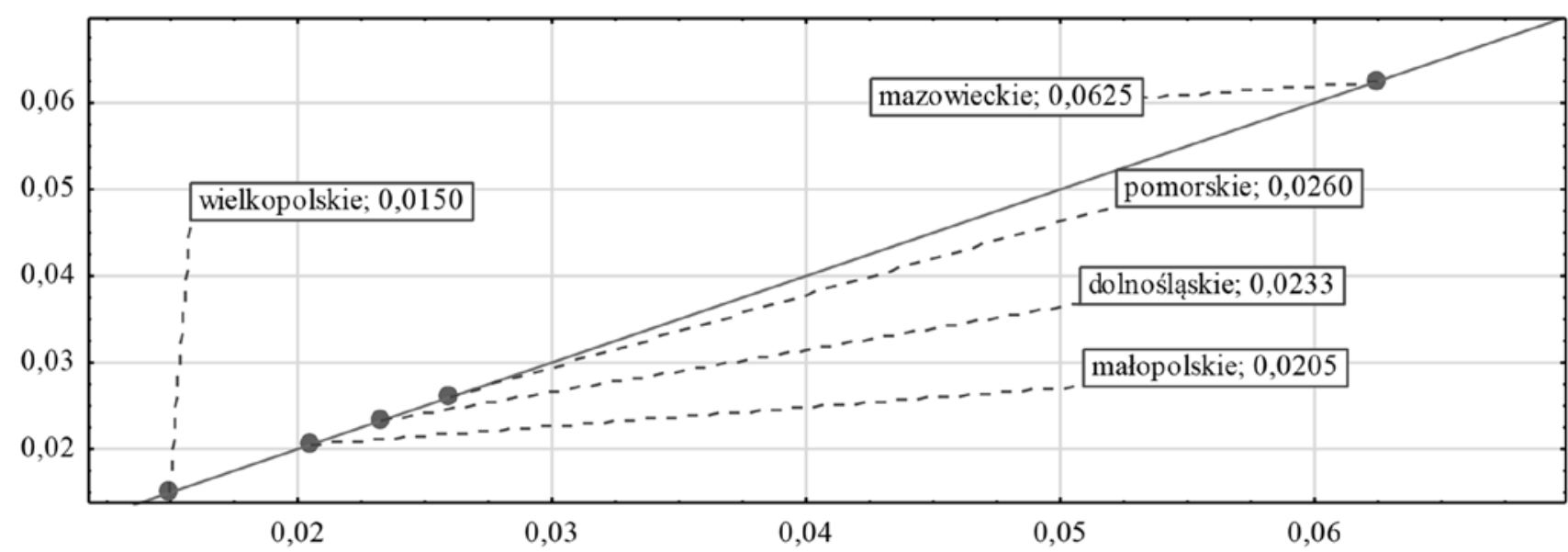

Figure 7. Ranking of the sum of the value of flats sold on the free market in 16 voivodships in Poland between 2015-2020 using the standardization for stimulants (scale from 0.0149 to 0.0630 )

Source: own study based on data obtained from the website: https://bdl.stat.gov.pl/, access: 03.12.2021

The observation of the normalization for stimulants shows that the Mazowieckie Voivodship is the highest one in the ranking with the result of 0,0625 . This is where the price of $1 \mathrm{~m}^{2}$ and the number of apartments sold are highest. The next highest-ranked voivodships are a group similar to each other, ranging from 0,0205 to 0,0260 . They include: Pomorskie Voivodship 0,0260; Dolnośląskie 0,0233 and Małopolskie 0,0205. It is there that the sum of the sales value of flats between 2015-2020 is close to each other with slight deviations. The fifth place in the ranking presented in Figure 7 is the Wielkopolskie Voivodship with the result of 0,0150. Figure 8 shows a further part of the ranking of the sum of the value of flats sold in Poland in respective 16 voivodships between 2015-2020 on the adopted scale from 0 to 0,01 .

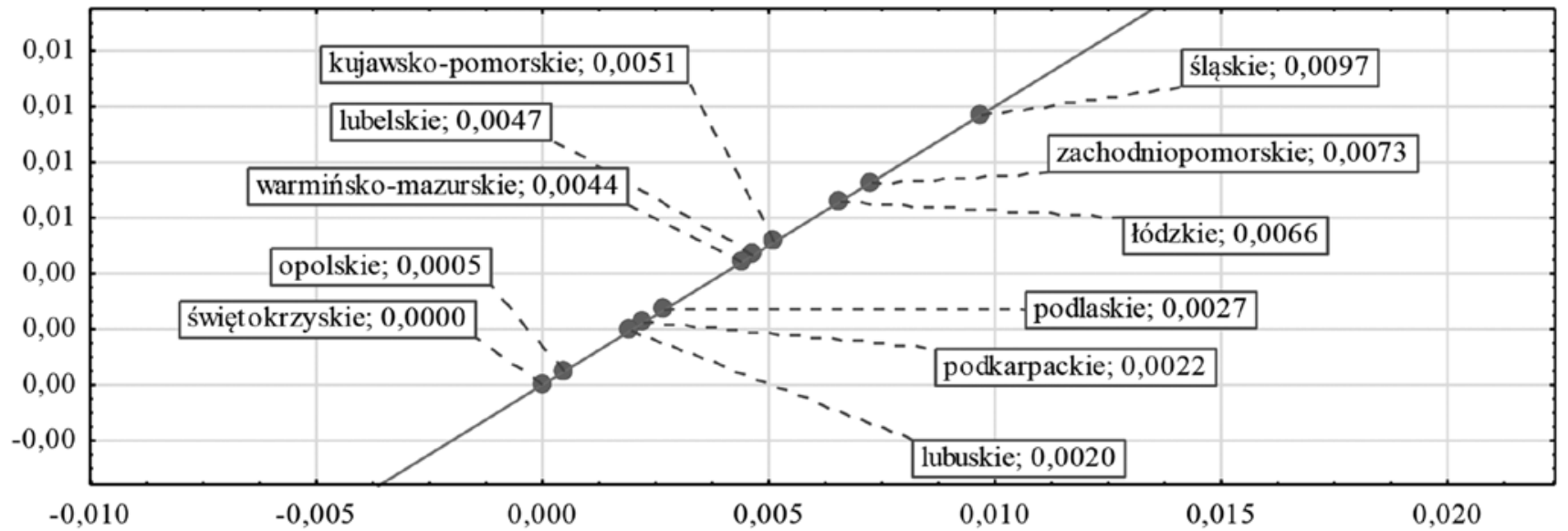

Figure 8. Ranking of the sum of the value of flats sold on the free market in 16 voivodships in Poland between 2015-2020 with the use of normalization for stimulants (scale from 0,00 to 0,01 )

Source: own study based on data obtained from the website: https://bdl.stat.gov.pl/, 03.12.2021

The observation of the further part of the ranking of data summarized in Figure 8 indicates five groups of variables in which there are data similar in terms of values. The highest one, with the result of 0,0097 , is the Śląskie Voivodship. Two subsequent voivodships form a separate group of data with similar values: Zachodniopomorskie 0,0073 and Łódzkie 0,0066 .

The third group of variables includes three voivodships: Kujawsko-Pomorskie 0,0051, Lubelskie 0,0047 and Warmińsko-Mazurskie 0,0044. 
The fourth group includes three voivodships with the following results: Podlaskie 0,0027 , Podkarpackie 0,0022 and Lubelskie $0,0020$.

The lowest fifth group in the ranking is two voivodships: Opolskie 0,0005 and Świętokrzyskie 0,0000. It is there that the sum of the sale value of apartments between 2015-2020 was by far lowest. It should be emphasized that the average price of $1 \mathrm{~m}^{2}$ of living space in the Świętokrzyskie Voivodship (PLN 3 811) was much higher than that in Opolskie (PLN 3 039) which proves that there were the lowest sales of apartments in this voivodship in Poland between 2015-2020 (Fig. 3).

\section{Summary and conclusions}

The research shows that the highest arithmetic mean of prices for $1 \mathrm{~m}^{2}$ of living space in Poland in 2020 was in the Mazowieckie Voivodship and amounted to PLN 6 949. The second place in the ranking is taken by Małopolskie Voivodship with the result of PLN 6 167. The third Pomorskie 5326 zloty. On the other hand, for the 16 analyzed voivodships, the lowest arithmetic mean of prices per $1 \mathrm{~m}^{2}$ of living space was recorded in Opolskie: PLN 3039.

The COVID-19 pandemic in 2020 led to changes in the value of apartment sales in Poland. In ten out of sixteen voivodships in Poland, in 2020, compared to 2019, decreases in the number of apartments sold were observed: 1 - dolnośląskie: -5 388; 2 - zachodniopomorskie: -4 201; 3 - małopolskie: -1 098; 4 - kujawsko-pomorskie: -1 016; 5 - podkarpackie: -684; 6 - pomorskie - 668; 7 - warmińsko-mazurskie: -222; 8 - śląskie: - 184; 9 - podlaskie: - 143; 10 - lubuskie: -89 .

Only in six voivodships there were increases in the sale of the number of apartments in 2020 compared to 2019: 1 - mazowieckie: 1 293; 2 - wielkopolskie: 1 292; 3 - opolskie: 452; 4 - lubelskie: 450; 5 - łódzkie: 423; 6 - świętokrzyskie: 365.

The use of standardization for stimulants allowed for the examination of the similarities and differences in terms of the sum of the value of apartment sales in 16 voivodships in Poland between 2015-2020.

The Mazowieckie Voivodship had the greatest rank in the analysis of the total value of apartment sales in Poland between 2015-2020 with the result of 0,0625, thus constituting a separate strong group. Housing prices in this voivodship, despite the impact of the COVID-19 pandemic, are rising, as is the number of apartments sold. According to the author, this voivodship is one of the best for financial investments in the form of, for instance, the purchase of flats - in order to allocate the available financial resources.

The next investment-friendly voivodships, which achieved the highest rank during the application of stimulants when considering the increase in apartment sales in 16 voivodships in Poland in dynamic terms, are: Pomorskie $(0,0260)$, Dolnośląskie $(0,0233)$ and Małopolskie $(0,0205)$. The voivodship similar to the three above, constituting a separate group at the same time, is the Wielkopolskie Voivodship $(0,0150)$. The remaining eleven voivodships achieved a value below 0,01 after the application of the stimulant. These voivodships can be included in five groups of dependent variables: the highest one with a result of 0,0097 is the Śląskie Voivodship, the next group is: Zachodniopomorskie 0,0073 and Lódzkie 0,0066. The third group included: Kujawsko-Pomorskie 0,0051, Lubelskie 0,0047 and Warmińsko-Mazurskie 0,0044. The fourth includes: Podlaskie 0,0027, Podkarpackie 0,0022 and Lubelskie 0,0020 . The lowest fifth group in the ranking is two voivodships: Opolskie 0,0005 and Świętokrzyskie 0,0000 .

The participatory observation shows that since the second quarter of 2020, the increase in flat prices in Poland has slowed down and the reason was the continuous reduced demand related to apartment rental caused by distant work, teaching and other restrictions.

The obtained research results are extremely important from the point of view of the main micro- and macroeconomic problems, as they allow to make many decisions related to the planning of the purchase and sale of apartments in various regions of Poland in terms of, for example, investments aimed at a good allocation of financial resources. 
The return to the pre-COVID-19 situation will require even more intensive attempts to contain the spread of the infectious disease through the continuous growth of the vaccinated population and the subsidizing of sectors that suffer losses from persistent diseases and require temporary financial support (Jurgilewicz et al., 2021).

An element influencing the level of security of citizens is the obligation of the state to combat epidemic diseases (Grabowski, 2016). Public authorities must focus on ensuring the security of their citizens, both in the economic context and for the protection of people's health and life. Therefore, in order to be able to talk about the improvement of the condition of the economy and the return to the situation from before the Covid-19 pandemic, the state must take account of not only matters related to the containment of the pandemic, but also matters related to the economic security of the state and human safety. The conducted research clearly showed how much of an impact on the state's economy, with particular emphasis on the subject of research presented in the article, which is the apartment trade market, has a random incident, such as a pandemic, and how difficult it is to return to the conditions before Covid-19.

\section{References:}

Beňuška, T., Nečas, P. 2021. On societal security of the state: applying a perspective of sustainability to immigration. Entrepreneurship and Sustainability Issues, 9(2), 473-487. http://doi.org/10.9770/jesi.2021.9.2(31)

Brzeziński, M. 2009. Rodzaje bezpieczeństwa państwa (Kinds of state security) [in:] Bezpieczeństwo wewnętrzne państwa. Wybrane zagadnienia (Internal security of the state. Selected Issues), eds. S. Sułowski, M. Brzeziński, Warszawa.

Chehabeddine, M., Tvaronavičienè, M. 2020. Securing Regional Development. Insights into Regional Development, $2(1)$, 430-442. http://doi.org/10.9770/IRD.2020.2.1(3)

Czaputowicz, J. 2003. Kryteria bezpieczeństwa międzynarodowego państwa - aspekty teoretyczne (State international security criteria theoretical aspects) [in:] Kryteria bezpieczeństwa międzynarodowego państwa (State international security criteria), eds. S. Dębski, B. Górka - Winter, Warszawa

Grabowska S. 2016. Bezpieczeństwo państwa (State security) [in:] Kategoria bezpieczeństwa w regulacjach konstytucyjnych i praktyce ustrojowej państw Grupy Wyszehradzkiej (The category of security in the constitutional regulations and systemic practice of the Visegrad Group countries), eds. A. Bień - Kacała, J. Jirásek, L. Cibulka, T. Drinóczi, Toruń

Grabowski, R.2016. Bezpieczeństwo a inne wartości konstytucyjnie chronione (Security and other constitutionally protected values) [in:] Kategoria bezpieczeństwa w regulacjach konstytucyjnych i praktyce ustrojowej państw Grupy Wyszehradzkiej (The category of security in the constitutional regulations and systemic practice of the Visegrad Group countries), eds. A. Bień - Kacała, J. Jirásek, L. Cibulka, T. Drinóczi, Toruń

Jurgilewicz, M., Malec, N., Piwowarski, J., Kozicki, B. 2021. Forecasting the Reserve Money of the Central Bank of Poland in the Aspects of Economy Security. Journal of Security and Sustainability Issues, 11(1), 525-536. https://doi.org/10.47459/jssi.2021.11.48

Khalatur, S., Masiuk, Y., Kachula, S., Brovko, L., Karamushka, O., Shramko, I. 2021. Entrepreneurship development management in the context of economic security. Entrepreneurship and Sustainability Issues, 9(1), 558-573. http://doi.org/10.9770/jesi.2021.9.1(35)

Kitler, W. 2011. Bezpieczeństwo narodowe RP. Podstawowe kategorie. Uwarunkowania. System (National security of the Republic of Poland. Basic categories. Conditions. System), Warszawa.

Kozicki, B., Mitkow, Sz., Sowa, B. 2021. Prognozowanie w obszarze zakupu nieruchomości w Polsce na 2021 rok w aspekcie bezpieczeństwa ekonomicznego (Forecasting in the area of real estate purchase in Poland for 2021 in terms of economic security). Nowoczesne Systemy Zarzadzania, 2. http://doi.org/10.37055/nsz/139361

Łuniewska, M., Tarczyński, W. 2006. Metody wielowymiarowej analizy porównawczej na rynku kapitałowym (Methods of multidimensional comparative analysis on the capital market), Wydawnictwo Naukowe PWN, Warszawa.

Matuka A., 2020, COVID-19 Outbreak and US Economic Policy Uncertainty: An ARDL Approach. SSRN Electronic Journal, https:// www.researchgate.net/publication/344083397

Meidute - Kavaliauskienè, I., Dudzevičiūtè, G., Šimelytė, A., Maknickienė, N. 2021. Sustainability and regional security in the context of Lithuania. Entrepreneurship and Sustainability Issues, 8(3), 248-266. http://doi.org/10.9770/jesi.2021.8.3(14)

Mitkow, Sz., Tomaszewski, J., Kozicki, B. 2021. Bezpieczeństwo militarne a potencjat osobowy Sił Zbrojnych RP (Military security and the personnel potential of the Polish Armed Forces), Wydawnictwo Wojskowa Akademia Techniczna, Warszawa. 
Nguyen, M.L.T., Bui, T.N. (2020). The financial development and the real estate market in Vietnam: A study in case of the global financial crisis. Entrepreneurship and Sustainability Issues, 8(2), 960-971. http://doi.org/10.9770/jesi.2020.8.2(58)

Nurzyńska, A. 2016. Bezpieczeństwo usług w międzynardowym transporcie lotniczym przewozów pasażerskich (Security of services in international passenger air transport), Wydawnictwo Naukowe SOPHIA, Katowice.

Owsiak, S. 2015. Finanse (Finances), Polskie Wydawnictwo Ekonomiczne, Warszawa.

Panek, T., Zwierzchowski, J. 2013. Statystyczne metody wielowymiarowej analizy porównawczej. Teoria i zastosowania (Statistical methods of multivariate comparative analysis. Theory and Applications), Oficyna Wydawnicza Szkoły Głównej Handlowej w Warszawie, Warszawa.

Periokaite, P., Dobrovolskiene, N. 2021. The impact of COVID-19 on the financial performance: a case study of the Lithuanian transport sector. Insights into Regional Development, 3(4), 34-50. http://doi.org/10.9770/IRD.2021.3.4(3)

Rynek Nieruchomości a Covid-19 (The Real Estate Market and Covid-19), 2021 https://gethome.pl/blog/rynek-nieruchomosci-covid-19/

Satomi, E., et al. 2020. Alocação justa de recuros de saúde escassos diante da pandemia de COVID-19 Considerações éticas. Einstein" São Paulo, 18(2), 1-5. http://doi.org/10.31744/einstein journal/2020AE5775

Szubrycht, T. 2006. Współczesne aspekty bezpieczeństwa (Contemporary aspects of security). Zeszyty Naukowe Marynarki Wojennej, 4 (167), 87-98.

Wojtaszczyk, K. A. 2009. Bezpieczeństwo państwa - konceptualizacja pojęć (State security - conceptualization of terms) [in:] Bezpieczeństwo państwa. Wybrane problemy (State security. Selected problems), eds. K. A. Wojtaszczyk, A. Materska - Sosnowska, Warszawa.

Zasięg koronawirusa Covid-19 (Covid-19 Coronavirus Coverage), 2021 https://www.medonet.pl/zdrowie/zdrowie-dla-kazdego,zasieg-koronawirusa-covid-19--mapa-,artykul,43602150.html

Zhu, N., Zhang, D., Wang, W., Li, X., Yang, B., Song, J., et al. 2020. A Novel Coronavirus from Patients with Pneumonia in China. New England Journal of Medicine.

Zięba, R. 2008. Pozimnowojenny paradygmat bezpieczeństwa międzynarodowego (The post-Cold War paradigm of international security) [in:] Bezpieczeństwo międzynarodowe po zimnej wojnie (International security after the Cold War), ed. R. Zięba, Warszawa

Zwierzchowski, E. 2009. Bezpieczeństwo obywateli (Security of citizens) [in:] Konstytucja Rzeczypospolitej Polskiej. Komentarz encyklopedyczny (The Constitution of the Republic of Poland. Encyclopedic commentary), eds. W. Skrzydło, S. Grabowska, R. Grabowski, Warszawa.

Bartosz KOZICKI is an assistant professor at the Military University of Technology, PL. Research interests: national security, internal security.

ORCID ID: 0000-0001-6089-952x.

Andrzej WLOCH is a Professor at the Rzeszow University of Technology, PL. Research interests: discrete mathematics, graph theory, combinatorics.

ORCID ID: 0000-0003-1789-6280.

Radosław GRABOWSKI is the Professor at the University of Rzeszow, PL. Research interests: law, internal security. ORCID ID: 0000-0003-3362-7363.

Szymon MITKOW is a Professor at the Military University of Technology, PL. Research interests: national security, internal security. ORCID ID: 0000-0003-2845-2589. 